\title{
Analisis Kesulitan Penyelesaian Soal Matematika Ditinjau Dari Kecerdasan Emosional Mahasiswa Di Kabupaten Tulungagung
}

\author{
Ratri Candra Hastari \\ STKIP PGRI Tulungagung; ratricandrahastari@gmail.com
}

Dikirim: 6 Desember 2017; Diterima: 31 Juli 2018; Dipublikasikan: 25 September 2018 Cara sitasi: Hastari, R. C. 2018. Analisis Kesulitan Penyelesaian Soal Matematika Ditinjau Dari Kecerdasan Emosional Mahasiswa Di Kabupaten Tulungagung. JNPM (Jurnal Nasional Pendidikan Matematika) Vol. 2(2), Hal.180-196.

\begin{abstract}
Abstrak. Kesulitan pada penyelesaian soal uraian diakibatkan oleh ketidakmampuan siswa atau mahasiswa dalam memahami soal hal ini disebabkan akibat kurang pengetahuan tentang konsep atau beberapa istilah yang diketahui. Penelitian ini bertujuan untuk mendeskripsikan kesulitan pada penyelesaian soal ditinjau dari Kecerdasan Emosional Mahasiswa di Kabupaten Tulungagung. Hasil penelitian ini diharapkan bermanfaat untuk: membantu mahasiswa untuk memperbaiki dan mengurangi kesulitan pada penyelesaian soal dan dapat digunakan sebagai pertimbangan dosen dalam memberikan langkah-langkah pembelajaran yang tepat untuk mengatasi kesulitan pada penyelesaian soal yang dialami oleh mahasiswa. Instrument penelitian yang digunakan adalah angket dan soal tes. Pendekatan yang digunakan dalam penelitian ini adalah kualitatif, sehingga data yang terkumpul dalam penelitian ini dianalisis dengan menggunakan metode analisis kualitatif. Analisis data dalam penelitian kualitatif dilakukan sejak sebelum memasuki lapangan, selama di lapangan, dan setelah selesai di lapangan. Hasil angket menunjukkan terdapat tiga kategori kecerdasan emosional mahasiswa, kategori rendah, sedang, dan tinggi. Berdasarkan kategori kecerdasan emosional mahasiswa kemudian dilakukan analisis kesulitan mahasiswa dalam menyelesaikan soal-soal persamaan diferensial.
\end{abstract}

Kata kunci: Kecerdasan Emosional, Kesulitan, Soal Matematika

Abstract. Difficulties in solving the problem description caused by the inability of students or students in understanding this matter due to lack of knowledge about the concept or some terms are known. This study aims to describe the difficulty in solving the problem in terms of Student Emotional Intelligence in Tulungagung District. The results of this study are expected to be useful for: helping students to improve and reduce 
the difficulty in solving problems and can be used as a consideration of lecturers in providing appropriate learning steps to overcome difficulties in solving problems experienced by students. The research instrument used was questionnaire and test question. The approach used in this research is qualitative, so the data collected in this study were analyzed by using qualitative analysis method. Data analysis in qualitative research conducted since before entering field, during in field, and after finished in field. The questionnaire results show that there are three categories of students' emotional intelligence, low, medium, and high category. Based on the category of students' emotional intelligence then conducted analysis of student difficulties in solving problems of differential equations.

Keywords: Emotional Intelligence, Difficulty, Mathematical Problem

\section{Pendahuluan}

Usaha untuk meningkatkan kualitas pendidikan, khususnya pendidikan matematika telah banyak dilakukan, bahkan terus-menerus diupayakan, namun hasil yang dicapai belum sesuai dengan harapan. Kenyataan yang terjadi di lapangan materi matematika masih dirasakan sulit oleh sebagian besar siswa dan beberapa siswa bahkan merasa takut untuk mempelajari matematika mulai dari SD sampai sekolah lanjutan.

Hal ini juga terjadi pada mahasiswa program studi pendidikan matematika di STKIP PGRI Tulungagung. Mereka mengalami kesulitan dalam menyelesaikan soal-soal pada mata kuliah persamaan diferensial. Berdasarkan hal tersebut peneliti tertarik untuk menganalis kesulitan yang dialami mahasiswa dalam menyelesaikan soal-soal pada mata kuliah persamaan diferensial yang ditinjau dari kecerdasan emosional mahasiswa.

Kecerdasan emosional adalah kemampuan seseorang dalam menggunakan atau mengelola emosi baik pada diri sendiri maupun ketika berhadapan dengan orang lain, dan menggunakannya secara efektif untuk memotivasi diri dan bertahan pada tekanan, serta mengendalikan diri untuk mencapai hubungan yang produktif.

Menurut Goleman (Baharuddin dan Wahyuni, 2015) membagi kecerdasan emosi atas lima komponen, yang dapat menjadi pedoman untuk mencapai kesuksesan dalam kehidupan sehari-hari, yaitu:

a. Kesadaran diri 
Kesadaran diri adalah kemampuan dalam mengenali perasaan sewaktu perasaan itu terjadi. Kesadaran diri merupakan dasar dari kecerdasan emosional. Pada tahap ini diperlukan adanya pemantauan perasaan dari waktu ke waktu agar timbul pemahaman tentang diri sendiri.

\section{b. Pengaturan diri}

Pengaturan diri berarti pengelolaan impuls dan perasaan yang menekan, agar dapat terungkap dengan tepat. Hal ini merupakan kecakapan yang sangat bergantung pada kesadaran diri. Emosi dikatakan berhasil dikelola apabila mampu menghibur diri ketika ditimpa kesedihan, dapat melepas kecemasan, kemurungan atau ketersinggungan dan bangkit kembali dengan cepat dari semua itu.Sebaliknya, orang yang buruk kemampuannya dalam mengelola emosi akan terus menerus bertarung melawan perasaan murung atau melarikan diri pada hal-hal yang merugikan diri sendiri. Pengaturan diri terdiri atas lima kecakapan, yaitu pengendalian diri, dapat dipercaya, kehati-hatian, adaptabilitas, dan inovasi.

\section{c. Motivasi}

Dengan kemampuan memotivasi diri sendiri yang dimilikinya, seseorang akan cenderung memiliki pandangan positif dalam menilai segala sesuatu yang terjadi dalam dirinya.

\section{d. Empati}

Empati atau mengenal emosi orang lain dibangun berdasarkan padakesadaran diri. Jika seseorang terbuka pada emosi diri sendiri, maka dapat dipastikan bahwa ia terampil membaca emosi orang lain. Sebaliknya orang yang tidak mampu menyesuaikan diri dengan emosinya sendiri dapat dipastikan tidak akan mampu menghormati perasaan orang lain.

e. Keterampilan sosial

Keterampilan sosial merupakan seni dalam membina hubungan dengan orang lain yang mendukung keberhasilan dalam bergaul dengan orang lain. Tanpa memiliki keterampilan seseorang akan mengalami kesulitan dalam pergaulan sosial. 
Goleman mengatakan bahwa kecerdasan emosi juga dipengaruhi oleh faktor internal dan eksternal, diantaranya faktor otak, faktor keluarga, faktor lingkungan sekolah.

Berdasarkan uraian tersebut, maka faktor-faktor yang mempengaruhi terbentuknya kecerdasan emosional adalah:

\section{a. Faktor otak}

La Doux (dalam Baharuddin, 2015) mengungkapkan bagaimana arsitektur otak memberi tempat istimewa bagi amigdala sebagai penjaga emosi, penjaga yang mampu membajak otak. Amigdala adalah spesialis masalahmasalah emosional.

\section{b. Fungsi lingkungan keluarga}

Orang tua memegang peranan penting terhadap perkembangan kecerdasan emosional anak. Goleman berpendapat bahwa lingkungan keluarga merupakan sekolah pertama bagi anak untuk mempelajari emosi.Dari keluargalah seorang anak mengenal emosi dan yang paling utama adalah orang tua.

\section{c. Faktor lingkungan sekolah}

Dalam hal ini, lingkungan sekolah merupakan faktor penting kedua setelah sekolah, karena di lingkungan ini anak mendapatkan pendidikan lebih lama. Guru memegang peranan penting dalammengembangkan potensi anak melalui beberapa cara, diantaranya melalui teknik, gaya kepemimpinan, dan metode mengajar sehingga kecerdasan emosional berkembang secara maksimal.

\section{d. Faktor lingkungan dan dukungan sosial}

Dukungan dapat berupa perhatian, penghargaan, pujian, nasihat atau penerimaan masyarakat. Semuanya memberikan dukungan psikis atau psikologis bagi anak. Dukungan sosial diartikan sebagai suatu hubungan interpersonal yang didalamnya satu atau lebih bantuan dalam bentuk fisik atau instrumental, informasi dan pujian. Dukungan sosial cukup mengembangkan aspek-aspek kecerdasan emosional anak, sehingga 
memunculkan perasaan berharga dalam mengembangkan kepribadian dan kontak sosialnya.

Berdasarkan latar belakang penelitian di atas, maka rumusan masalah yang dapat dimunculkan pada penelitian ini adalah : "Bagaimanakah kesulitan pada penyelesaian soal ditinjau dari Kecerdasan Emosional Mahasiswa di Kabupaten Tulungagung". Maka tujuan penelitian ini adalah "Untuk mendeskripsikan kesulitan pada penyelesaian soal ditinjau dari Kecerdasan Emosional Mahasiswa di Kabupaten Tulungagung".

\section{Metode Penelitian}

Rancangan penelitian yang digunakan dalam penelitian ini adalah penelitian kualitatif. Rancangan penelitian kualitatif dipilih karena bersifat alami dan ditampilkan sebagaimana adanya tanpa unsur manipulasi atau perlakuan khusus terhadap objek penelitian. Sukmadinata (2010: 94) menyatakan bahwa "penelitian kualitatif ditujukan untuk mendeskripsikan dan menganalisis peristiwa-peristiwa sebagaimana terjadi secara alami yang mempunyai dua tujuan utama, yaitu pertama, menggambarkan dan mengungkapkan (to describe and explore) dan kedua, menggambarkan dan menjelaskan (to describe and explain)". Peneliti menggunakan penelitian kualitatif yang bersifat deskriptif dengan analisis pendekatan induktif yang pengumpulan datanya sebagai sumber langsung dengan instrumen kunci peneliti sendiri.

Sesuai dengan rancangan penelitian ini, yaitu penelitian kualitatif maka kehadiran peneliti di tempat penelitian mutlak diperlukan karena peneliti bertindak sebagai instrumen utama yaitu berperan sebagai pengumpul data, penganalisis data, penyimpulan data, juga sebagai pewawancara dan sekaligus sebagai pelapor hasil temuan.

Analisis data pada penelitian ini dilakukan sejak awal turun ke lokasi melakukan pengumpulan data, dengan cara "mengangsur atau menabung" informasi, mereduksi, mengelompokkan dan seterusnya sampai terakhir memberi interprestasi.

Wawancara dilakukan untuk mengetahui kesulitan konsep yang dialami mahasiswa tentang materi persamaan diferensial, wawancara dengan 
beberapa mahasiswa yang mengalami kesulitan dalam menyelesaikan soalsoal dalam tes tertulis. Wawancara ini bertujuan untuk mengetahui penyebab mereka mengalami kesulitan dalam menyelesaikan soal.

Pengumpulan data pada penelitian ini dilakukan dengan menggunakan instrumen penelitian, yaitu soal tes dan angket kecerdasan emosional. Instrumen penelitian sebelum digunakan untuk penelitian instrumen diujicobakan di kelas uji coba. Uji coba yang dilakukan untuk mengetahui validitas dan reliabilitas soal tes yang terdiri dari empat butir soal dan angket kecerdasan emosional yang terdiri dari 22 nomer . Validitas item (butir soal) dihitung untuk mengetahui seberapa jauh hubungan antara jawaban suatu butir soal dengan skor total yang telah ditetapkan. sehingga untuk mengetahui validitas item ini digunakan rumus korelasi product moment (Arikunto, 2010) sebagai berikut

$$
r_{x y}=\frac{N \sum x y-\left(\sum x\right)\left(\sum y\right)}{\sqrt{\left\{N \sum x^{2}-\left(\sum x\right)^{2}\right\}\left\{N \sum y^{2}-\left(\sum y\right)^{2}\right\}}}
$$

dengan :

$\mathrm{x}$ : skor butir soal

$\mathrm{y}$ : skor total

$\mathrm{r}_{\mathrm{xy}}$ : koefisien korelasi antara skor butir dengan skor total

$\mathrm{N}$ : banyaknya siswa yang mengikuti tes

Nilai rxy diinterpretasikan sebagai berikut :

$0,80 \leq \mathrm{rxy}<1,00$ : validitas butir tes sangat tinggi

$0,60 \leq \mathrm{rxy}<0,80$ : validitas butir tes tinggi

$0,40 \leq$ rxy $<0,60$ : validitas butir tes cukup

$0,20 \leq \mathrm{rxy}<0,40$ : validitas butir tes rendah

$0,00 \leq \mathrm{rxy}<0,20$ : validitas butir tes sangat rendah

Butir tes dan angket dikatakan valid jika mempunyai validitas cukup, tinggi, atau sangat tinggi, sedangkan untuk butir-butir tes yang memiliki validitas rendah dan sangat rendah akan direvisi. 
Reliabilitas instrumen tes dihitung untuk mengetahui konsistensi hasil tes. Untuk menghitung reliabilitas untuk soal uraian/subyektif dapat digunakan rumus Alfa Chonbach sebagai berikut:

$$
r_{11}=\left(\frac{k}{k-1}\right)\left(1-\frac{\Sigma \sigma_{b}{ }^{2}}{\sigma_{t}{ }^{2}}\right)
$$

Dengan :

$r_{11} \quad=$ reliabilitas instrumen

$k \quad=$ banyaknya butir pertanyaan atau banyaknya soal

$\Sigma \sigma_{b}^{2} \quad=$ jumlah varians butir

$\sigma_{t}^{2} \quad=$ varians total

Langkah-langkah kegiatan analisis data:

Mereduksi data

Mereduksi data adalah kegiatan menyeleksi, memfokuskan dan menyederhanakan semua data yang telah diperoleh mulai dari awal pengumpulan data sampai penyusunan laporan penelitian. Hal ini dilakukan untuk memperoleh informasi yang jelas sehingga peneliti dapat menarik kesimpulan yang dapat dipertanggung jawabkan.

Penyajian data

Penyajian data merupakan kegiatan menyajikan hasil reduksi data secara naratif sehingga memungkinkan penarikan simpulan dan keputusan pengambilan tindakan

Penarikan kesimpulan dan verifikasi data

Penarikan kesimpulan/ verifikasi adalah kegiatan memberikan kesempatan terhadap hasil penafsiran dan evaluasi. Akan tetapi hasil simpulan yang diberikan dari data tersebut masih perlu diuji kebenarannya. Kegiatan ini mencakup pencarian makna dan memberi penjelasan

\section{Hasil dan Pembahasan}

Berdasarkan hasil uji coba di kelas B, untuk soal uraian dan perhitungan validitas serta reliabilitas diperoleh data bahwa seluruh soal yang terdiri dari 4 soal dinyatakan valid dan reliabel. Angket kecerdasan emosional yang 
telah dinyatakan valid oleh validator yaitu dosen bimbingan konseling maka angket diberikan ke mahasiswa untuk diisi sesuai dengan petunjuk yang ada pada angket kecerdasan emosional.

Observasi dilakukan oleh seorang observer, observer adalah anggota peneliti. Hasil pengamatan dari observer yaitu kegiatan pembelajaran sudah baik melibatkan mahasiswa, respons dosen terhadap mahasiswa baik, dosen juga sudah melaksanakan pembelajaran sesuai dengan kompetensi yang akan dicapai. adapun kekurangan dosen yaitu belum menunjukkan keterampilan dalam menggunakan media pembelajaran, dan pembelajaran cenderung menggunakan metode ceramah yang mengakibatkan mahasiswa kadang merasa bosan.

Aktivitas mahasiswa pada proses pembelajaran masih terdapat beberapa mahasiswa yang tidak merespons ketika dosen menjelaskan materi yang disampaikan, beberapa mahasiswa juga ada yang melamun saat proses pembelajaran berlangsung, bermain gadget sendiri, dan ketidaklengkapan buku catatan karena mahasiswa tidak mau mencatat materi yang disampaikan. Beberapa mahasiswa sudah terlibat aktif ketika dosen meminta untuk mengerjakan soal yang diberikan dan dikerjakan di papan tulis kemudian menjelaskan ke teman-temannya.

Kegiatan akhir pembelajaran tanpa adanya refleksi atau membuat rangkuman dari materi yang dipelajari pada saat itu oleh dosen dan mahasiswa.

Berdasarkan data hasil tes dan deksripsi kesulitan tampak bahwa ada beberapa mahasiswa mengalami kesulitan. Kesulitan yang dialami mahasiswa tersebut bervariasi dan terdapat mahasiswa yang tidak mengerjakan beberapa soal dari 4 soal yang diberikan. 
Tabel 1. Kesulitan Mahasiswa

\begin{tabular}{|c|c|c|c|c|c|}
\hline \multirow{2}{*}{ No } & \multirow[b]{2}{*}{$\begin{array}{l}\text { Inisial } \\
\text { Nama }\end{array}$} & \multicolumn{4}{|c|}{ Jenis Kesulitan Pada Butir Soal } \\
\hline & & 1 & 2 & 3 & 4 \\
\hline 1 & RI & Benar & kt & $\mathrm{Kg}$ & Benar \\
\hline 2 & $\mathrm{R} \mathbf{N}$ & Benar & Benar & kt & Ko \\
\hline 3 & SAD & Benar & Benar & kt & $\mathbf{K} \mathbf{h}$ \\
\hline 4 & $\mathrm{SJ}$ & Benar & Benar & Benar & Benar \\
\hline 5 & IIV 27 & Benar & Benar & Benar & kt \\
\hline 6 & DS & Benar & Benar & kcs & Benar \\
\hline 7 & DK & Benar & Benar & $\mathbf{K} \mathbf{k}$ & kt \\
\hline 8 & SU & $\begin{array}{l}\mathbf{K}_{0} \\
\mathbf{K}_{t}\end{array}$ & Benar & $\begin{array}{l}\mathrm{Kt} \\
\mathbf{K} \mathbf{h}\end{array}$ & $\mathrm{Kt}$ \\
\hline 9 & FA.A & Benar & Benar & Benar & $\begin{array}{l}\mathrm{Kt} \\
\mathrm{Kg}\end{array}$ \\
\hline 10 & NDP & Benar & Benar & $\mathrm{Kt}$ & $\mathrm{Kg}$ \\
\hline 11 & $A G$ & $\mathbf{K} \mathbf{t}$ & Benar & $\begin{array}{l}\mathrm{K} / \mathrm{h} \\
\mathrm{K} g\end{array}$ & $\mathrm{Kt}$ \\
\hline 12 & IP & Benar & Benar & $\mathrm{K} t$ & K K \\
\hline 13 & RF & Benar & $\mathrm{K} \mathrm{t}$ & Benar & $\mathrm{Kg}$ \\
\hline 14 & NF & Benar & Benar & $\mathrm{Kt}$ & K $k$ \\
\hline 15 & $T Z$ & Benar & Benar & $\begin{array}{l}\mathrm{Kt} \\
\mathrm{K} \mathrm{k}\end{array}$ & $\mathrm{Kt}$ \\
\hline 16 & IL & Benar & Benar & $\mathrm{Kg}$ & Benar \\
\hline 17 & LMI & Benar & Benar & $\mathrm{K} \cdot \mathrm{h}$ & Benar \\
\hline 18 & SR & Benar & Benar & Benar & $\mathbf{K h}$ \\
\hline 19 & DP & Benar & Benar & Benar & Benar \\
\hline 20 & RI & Benar & Benar & $\mathrm{Kt}$ & $\mathrm{Kg}$ \\
\hline 21 & SF & Benar & Benar & $\mathrm{K} h$ & Benar \\
\hline 22 & $A W$ & $\mathbf{K} t$ & Benar & $\mathrm{Kt}$ & Benar \\
\hline 23 & A.A & Benar & Benar & $\mathrm{Kt}$ & $\begin{array}{l}\mathrm{Kt} \\
\mathrm{K} \mathbf{k}\end{array}$ \\
\hline 24 & SH & Kk & $K_{\mathrm{t}} \mathrm{t}$ & $\begin{array}{l}\mathrm{Kt} \\
\mathrm{K} \mathrm{g}\end{array}$ & $\begin{array}{l}\text { K } \mathbf{k} \\
\mathbf{K} \mathbf{t}\end{array}$ \\
\hline 25 & YA & Benar & $\mathrm{K} / \mathrm{k}$ & $\mathrm{K} \mathrm{t}$ & Benar \\
\hline 26 & DA & Benar & Benar & $\mathrm{K} t$ & $\mathrm{Kg}$ \\
\hline
\end{tabular}

Keterangan :

$\mathrm{Kt}=$ Kesulitan menurunkan suatu fungsi (misal : fungsi trigonometri, fungsi eksponensial)

$\mathrm{Kk}=$ Kesulitan konsep (misal, kesulitan dalam mengoperasikan pangkat)

$\mathrm{Kh}=$ Kesalahan operasi hitung

Untuk mengetahui lebih lanjut tentang kesulitan mahasiswa, berikut secara rinci uraian analisis kesulitan mahasiswa dalam menyelesaikan persamaan diferensial. 


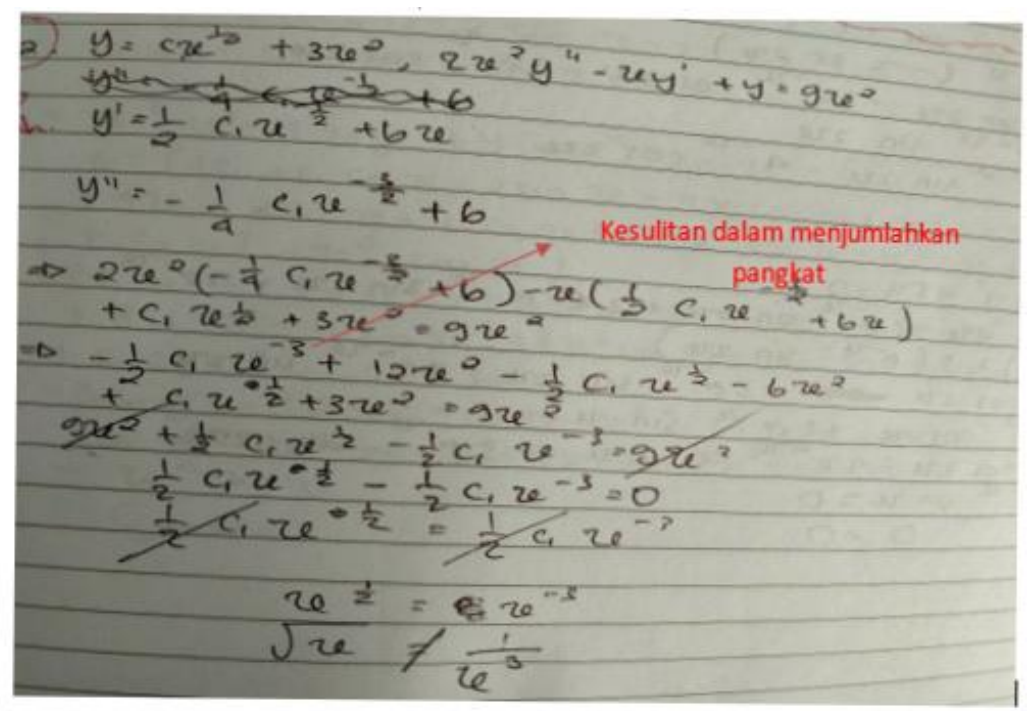

Gamabr 1. Jawaban Yuni Astriani (Kategori Rendah)

Dari jawaban mahasiswa terlihat bahwa mahasiswa salah dalam menjumlahkan pangkat. Hal tersebut berdampak pada proses selanjutnya dan juga pada hasil atau penyelesaian masalah.

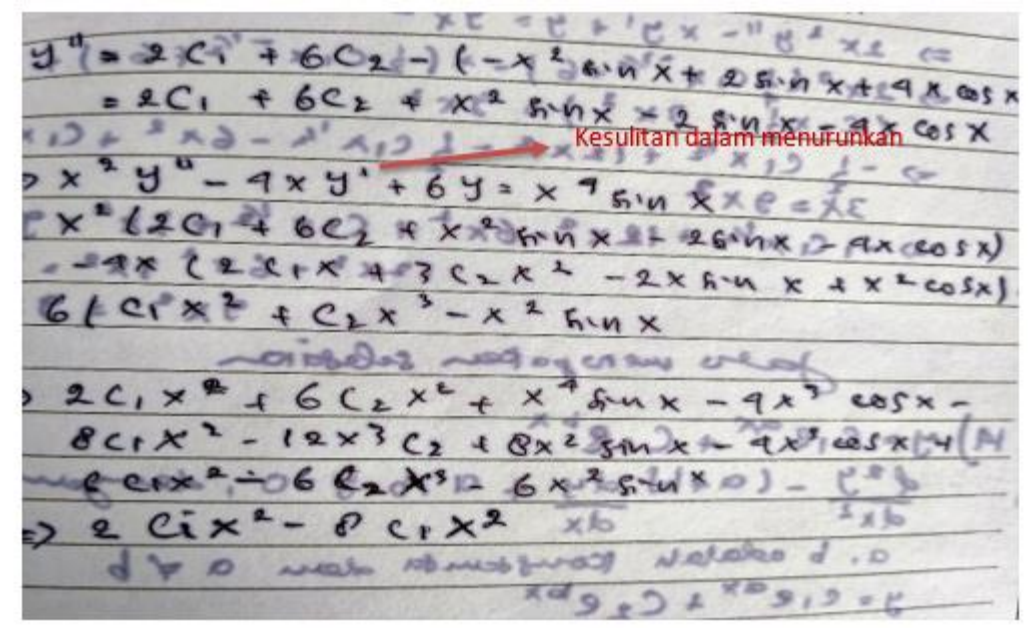

Gambar 2. Jawaban Roziqi Ilyas (Kategori Rendah)

Dari penyelesaian mahasiswa terlihat bahwa mahasiswa mengalami kesulitan dalam melakukan diferensial atau turunan. Apalagi yang dioperasikan bukan suatu bilangan tapi suatu variabel. Karena mengalami kebingungan akibatnya nomer tersebut tidak diselesaikan dengan baik. 


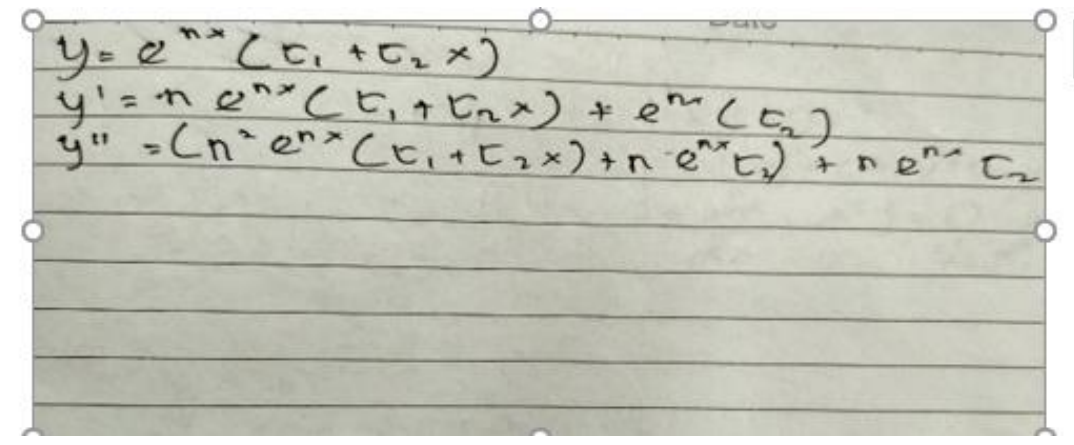

Gambar 3. Jawaban Roziqi Ilyas

Untuk nomer tiga, mahasiswa tersebut tidak bisa menyelesaikan. Mahasiswa merasa kesulitan dalam mensubtitusikan ke dalam persamaan diferensial.

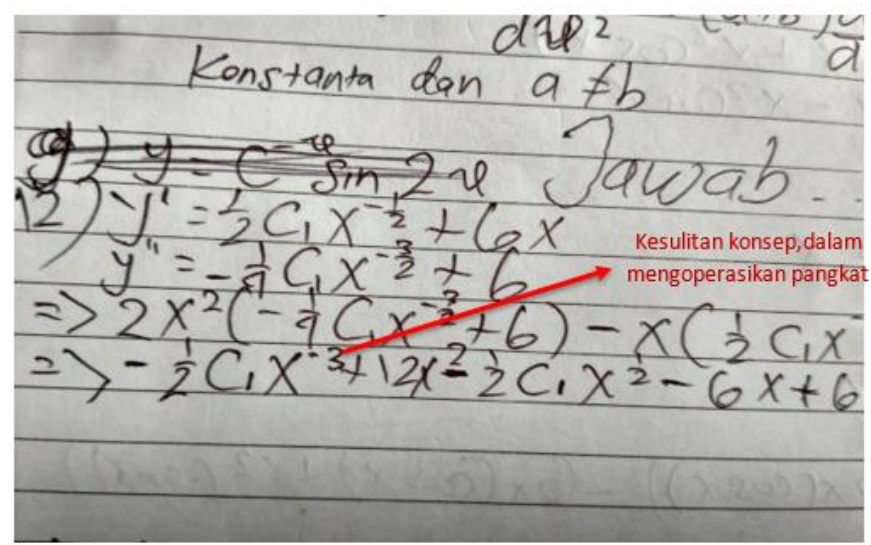

Gambar 4. Jawaban Syukron Hamdani (Kategori Rendah)

Dari jawaban mahasiswa di atas terlihat bahwa mengalami kesulitan dalam mengoperasikan penjumlahan pangkat. Seharusnya pangkatnya dijumlahkan tapi yang dilakukan adalah dikalikan.

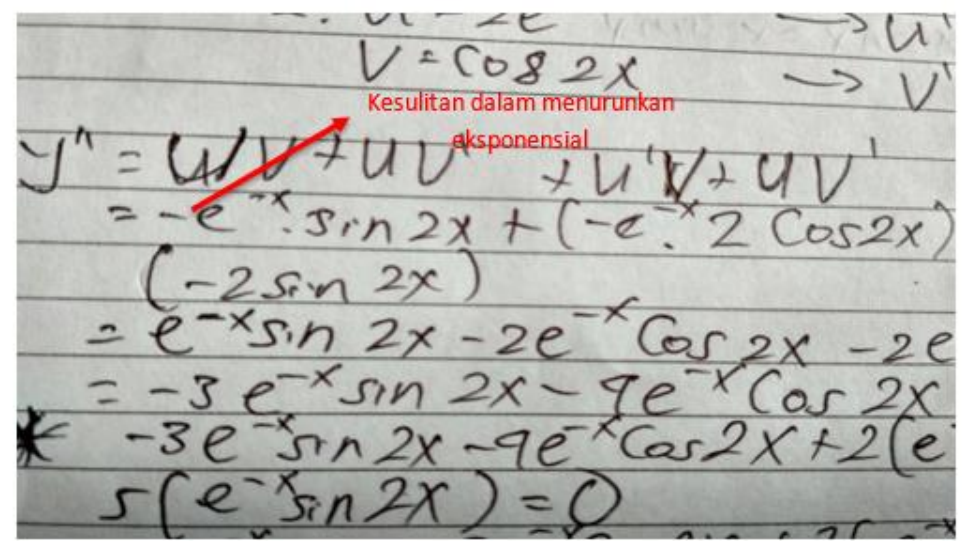

Gambar 5. Jawaban Syukron Hamdani 
Dari jawaban mahasiswa di atas terlihat bahwa mahasiswa salah dalam menurunkan eksponensial, ini Karena mahasiswa mengalami kesulitan dalam turunan bilangan eksponensial.

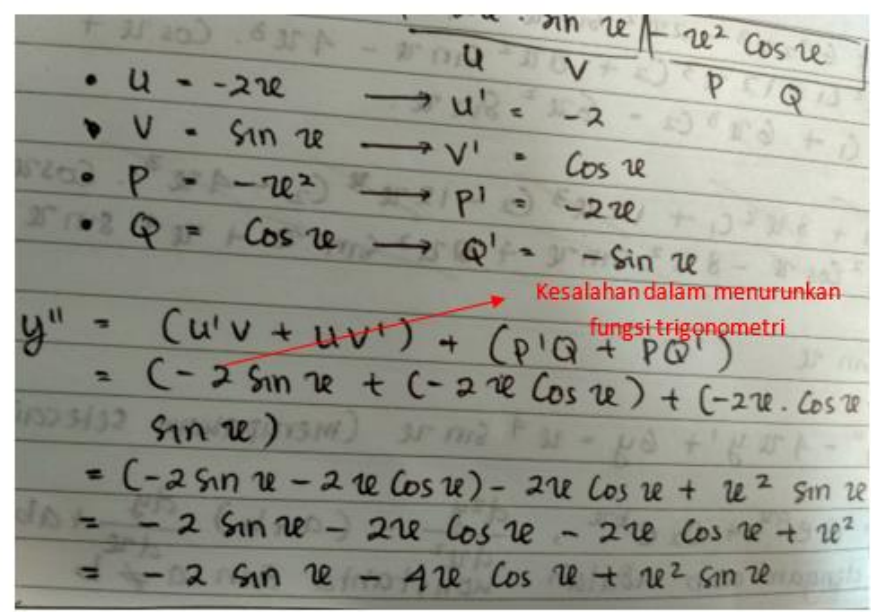

Gambar 6. Jawaban Alviana Widyawati(Kategori Sedang)

Dari jawaban di atas terlihat bahwa mahasiswa mengalami kesulitan dalam menurunkan suatu fungsi trigonometri, yang berakibat kesalahan dalam menyelesaikan soal.

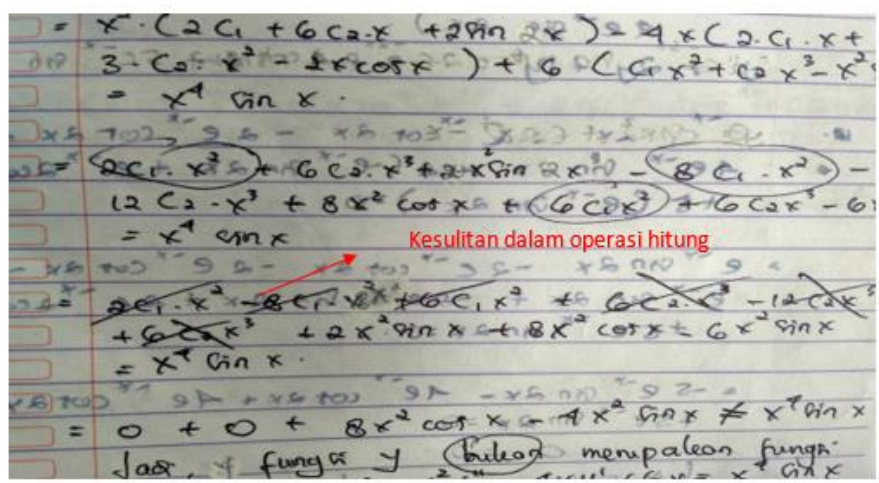

Gambar 7. Jawaban Siti Komariyah (Kategori Sedang)

Dari jawaban di atas terlihat bahwa mahasiswa kurang teliti dalam operasi hitung, sehingga penyelesaian menjadi salah. 


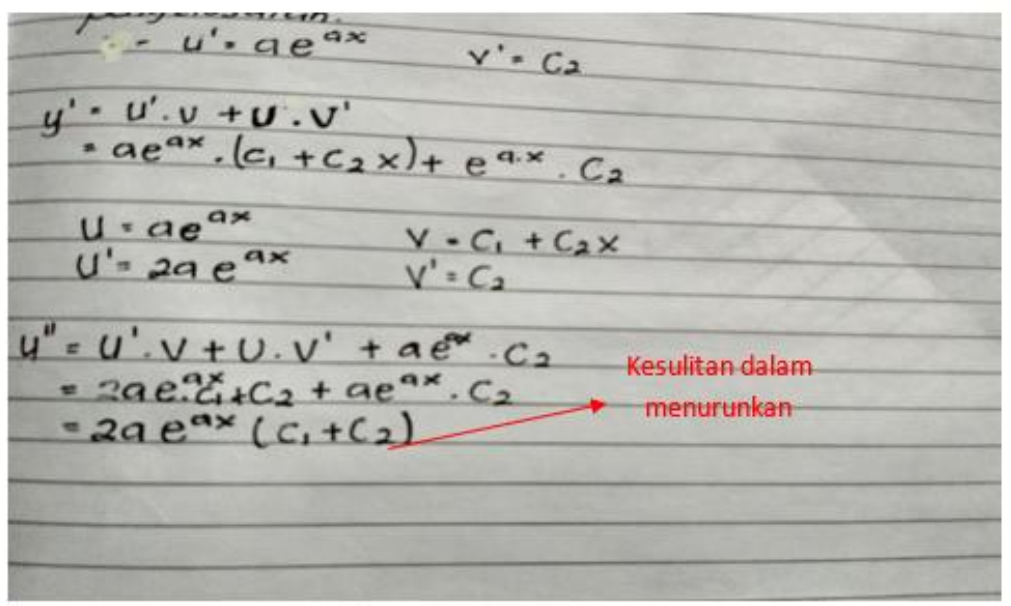

Gambar 8. Jawaban Ira Nuraini(Kategori Tinggi)

Tabel 2. Hasil Angket Kecerdasan Emosional

\begin{tabular}{|c|c|c|c|c|c|}
\hline NO. & NAMA & $\begin{array}{l}\text { KATEGORI } \\
\text { EQ }\end{array}$ & No & NAMA & KATEGORI EQ \\
\hline 1 & $\mathrm{RI}$ & Rendah & 14 & $\mathrm{NF}$ & Rendah \\
\hline 2 & $\mathrm{RN}$ & Tinggi & 15 & $\mathrm{TZ}$ & Sedang \\
\hline 3 & SAD & Sedang & 16 & II & sedang \\
\hline 4 & SJ & Tinggi & 17 & LM & Tinggi \\
\hline 5 & IN & Tinggi & 18 & SK & Sedang \\
\hline 6 & DS & Sedang & 19 & $\mathrm{DP}$ & Sedang \\
\hline 7 & $\mathrm{DN}$ & Sedang & 20 & $\mathrm{RL}$ & Tinggi \\
\hline 8 & SU & Sedang & 21 & SF & Sedang \\
\hline 9 & FAA & Sedang & 22 & AW & Sedang \\
\hline 10 & $\mathrm{NDP}$ & Sedang & 23 & $\mathrm{AA}$ & Rendah \\
\hline 11 & $\mathrm{AG}$ & Sedang & 24 & $\mathrm{SH}$ & Rendah \\
\hline 12 & IP & Sedang & 25 & YA & Rendah \\
\hline 13 & $\mathrm{RF}$ & Rendah & 26 & $\mathrm{DA}$ & Sedang \\
\hline
\end{tabular}

Dari jawaban mahasiswa di atas terlihat bahwa mahasiswa mengalami kesulitan dalam menurunkan suatu persamaan, sehingga mahasiswa kesulitan untuk menyelesaikan langkah selanjutnya.

Data yang diperoleh dari angket, kemudian diklasifikasikan ke dalam kriteria interpretasi skor. Untuk mencari kategori dikelompokkan menjadi 3 kategori yaitu tinggi, sedang dan rendah. Adapun langkah-langkah untuk mengklasifikasikan skor adalah sebagai berikut:

Menjumlahkan semua skor siswa 
Mencari nilai rata-rata $(\mathrm{Mean} / \overline{\mathrm{X}})$

$$
\begin{aligned}
& \bar{X}=\frac{\sum X}{N} \\
& \sum X=\text { Jumlah skor } \\
& N=\text { Jumlah siswa }
\end{aligned}
$$

1) Mencari simpangan baku (Standar Deviasi)

$$
\begin{aligned}
& S D=\sqrt{\frac{\sum X^{2}}{N}-\left(\frac{\sum X}{N}\right)^{2}} \\
& \frac{\sum X^{2}}{N}=\text { tiap skor dikuadratkan, kemudian dijumlahkan lalu dibagi } \mathrm{N} \\
& \left(\frac{\sum X}{N}\right)^{2}=\text { semua skor dijumlahkan, dibagi } \mathrm{N} \text {, lalu dikuadratkan }
\end{aligned}
$$

2) Menentukan batas-batas kategori

Tabel 2. Interval Skor Angket Intensitas Belajar

\begin{tabular}{ccc}
\hline No & Interval & Kategori \\
\hline 1 & $\mathrm{~S} \geq X+1 \mathrm{SD}$ & Tinggi \\
2 & $X-1 \mathrm{SD} \leq \mathrm{S}<X+1 \mathrm{SD}$ & Sedang \\
3 & $\mathrm{~S}<X-1 \mathrm{SD}$ & Rendah \\
\hline
\end{tabular}

Wawancara digunakan sebagai metode dalam pengumpulan data. Tujuan dari wawancara adalah untuk memeriksa kebenaran hasil analisis jawaban tes, serta untuk mengetahui jenis dari kesulitan yang dialami mahasiswa dalam menyelesaikan soal tes. Wawancara dilakukan terhadap mahasiswa yang jawaban tesnya telah dianalisis.

Setelah melakukan wawancara selanjutnya peneliti menganalisis hasil wawancara dengan mahasiswa sebagai subyek yang mengalami kesulitankesulitan dalam mengerjakan soal tes komposisi dua fungsi atau lebih. Berdasarkan petikan wawancara diperoleh data sebagai berikut:

Tabel 4. Hasil Wawancara

\begin{tabular}{llr}
\hline \multicolumn{1}{c}{ Nama Mahasiswa } & \multicolumn{1}{c}{ Hasil analisa wawancara } \\
\hline YA (kecerdasan emosional Kategori & $\begin{array}{l}\text { 1. Mahasiswa merasa kesulitan dalam } \\
\text { mengoperasikan } \\
\text { Rendah): }\end{array}$ & berpangkat. \\
\hline
\end{tabular}




\begin{tabular}{ll}
\hline Nama Mahasiswa & \multicolumn{1}{c}{ Hasil analisa wawancara } \\
\hline 2. Mahasiswa merasa kesulitan dalam \\
menurunkan suatu fungsi. \\
3. Mahasiswa merasa tidak menguasai \\
mata kuliah kalkulus sebagai mata \\
kuliah prasyarat persamaan \\
diferensial.
\end{tabular}

RI (kecerdasan emosional Kategori Rendah)
1. Mahasiswa merasa kesulitan dalam menurunkan suatu fungsi

2. Mahasiswa merasa kesulitan dalam melakukan operasi subtitusi ke dalam persamaan diferensial.

3. Mahasiswa merasa tidak memahami materi yang diberikan.

4. Mahasiswa merasa tidak menguasai materi kalkulus sebagai materi prasyarat untuk menempuh mata kuliah persamaan diferensial.
Hasil analisis wawancara dengan mahasiswa SH (kecerdasan emosional Kategori Rendah)
1. Mahasiswa merasa kesulitan dalam mengoperasikan berpangkat.

bilangan

2. Mahasiswa merasa kesulitan dalam menurunkan suatu fungsi, terutama fungsi eksponensial.

3. Mahasiswa merasa sering lupa dengan materi kalkulus, terutama materi diferensial atau turunan.
Hasil analisis wawancara dengan mahasiswa AW (kecerdasan emosional Kategori Sedang)
1. Mahasiswa merasa kesulitan dalam menurunkan suatu fungsi, terutama fungsi trigonometri.

2. Mahasiswa merasa sering lupa dengan materi kalkulus, terutama materi diferensial atau turunan.

\begin{tabular}{lr}
\hline $\begin{array}{l}\text { Hasil analisis wawancara dengan } \\
\text { mahasiswa SK (kecerdasan emosional }\end{array}$ & $\begin{array}{r}\text { 1. Mahasiswa tidak mengalami } \\
\text { kesulitan hanya kurang teliti dalam } \\
\text { Kategori Sedang) }\end{array}$ \\
\hline
\end{tabular}




\begin{tabular}{ll}
\hline \multicolumn{1}{c}{ Nama Mahasiswa } & \multicolumn{1}{c}{ Hasil analisa wawancara } \\
\hline & $\begin{array}{l}\text { 2. Mahasiswa terkadang lupa dengan } \\
\text { materi kalkulus, terutama materi } \\
\text { diferensial atau turunan. }\end{array}$ \\
\hline $\begin{array}{l}\text { Hasil analisis wawancara dengan } \\
\text { mahasiswa IN (kecerdasan emosional } \\
\text { Kategori Tinggi) }\end{array}$ & $\begin{array}{l}\text { 1. Mahasiswa merasa kesulitan dalam } \\
\text { menurunkan suatu fungsi, terutama } \\
\end{array}$ \\
& $\begin{array}{l}\text { fungsi eksponensial maupun fungsi } \\
\text { trigonotri. } \\
\text { 2. Mahasiswa merasa sering lupa } \\
\text { dengan materi kalkulus, terutama } \\
\text { materi diferensial atau turunan. }\end{array}$
\end{tabular}

\section{Simpulan dan Saran}

Berdasarkan tahap yang sudah diselesaikan maka dapat disimpulkan sebagai berikut : Penelitian ini cukup berjalan dengan lancar, pada tahap uji coba instrumen penelitian, observasi, pelaksanaan tes, maupun wawancara. Hasil angket menunjukkan terdapat tiga kategori kecerdasan emosional mahasiswa, kategori rendah, sedang, dan tinggi. Berdasarkan kategori kecerdasan emosional mahasiswa kemudian dilakukan analisis kesulitan mahasiswa dalam menyelesaikan soal-soal persamaan diferensial.

Setelah mengetahui jenis-jenis kesulitan yang dialami mahasiswa dan kategori kecerdasan emosional mahasiswa hendaknya dosen menentukan langkah pembelajaran yang tepat untuk meminimalisir kesulitan yang dilakukan mahasiswa dalam menyelesaikan soal. Dosen dapat menggunakan cara yaitu dengan menggunakan model pembelajaran yang menarik atau dengan bantuan media pembelajaran yang tepat agar mahasiswa merasa senang dengan materi yang diajarkan.

\section{Daftar Pustaka}

Arikunto, S. 2006. Prosedur Penelitian Suatu Pendekatan Praktik. Jakarta: RinekaCipta

Arikunto, S. 2010. Prosedur Penelitian Suatu Pendekatan Praktik. Jakarta: PT Rineka Cipta.

Baharudin. 2015. Teori Belajar dan Pembelajaran. Yogyakarta: Ar-ruzz Media.

Dalyono. 2007. Psikologi Pendidikan. Jakarta: RinekaCipta 
Hudojo, H. 2005. Pengembangan Kurikulum dan Pembelajaran Matematika. Malang: UM PRESS

Moleong, L. J. 2010. Metodologi Penelitian Kualitatif. Bandung: Remaja Rosdakarya.

Uno, H. 2014. Mengelola Kecerdasan Dalam Pembelajaran. Jakarta: PT Bumi Aksara.

Sugiyono. 2011. Metode Penelitian Kuantitatif, Kualitatif, dan RED, Bandung:Alfabeta

Sugiyono. 2017. Statistika Untuk Penelitian. Bandung: Alfabeta.

Suherman, E dan Udin, S dan Winataputra. 1993. Strategi Belajar dan Mengajar Matematika. Jakarta: Depdikbud.

Sukmadinata, N. S. 2010. Metode Penelitian Pendidikan. Bandung: Remaja Rosdakarya. 